\title{
Arab Countries Within the WTO
}

\author{
Sana Bou Dargham \\ Lebanese University, Lebanon
}

Doi: 10.19044/elp.v7no4a2 㞷L:http://dx.doi.org/10.19044/elp.v7no4a2

\begin{abstract}
While international trade is accelerating and encompassing more developing and emerging countries, it appears that the Arab countries are staying away from this process and their integration into world trade is encountering many obstacles. Faced with the dangers of bilateralism and the failure of further trade integration, it is clear to Arab countries that the multilateral framework of the World Trade Organization (WTO) remains the most conducive to protecting their interests. But their position within this organization remains marginal. This contribution attempts, precisely, to analyse the underlying reasons for this marginalization and the nature of the challenges facing the Arab countries within the WTO.
\end{abstract}

Keywords: WTO, multilateralism, Arab countries, international trade.

\section{Introduction}

The WTO is the only global international organization dealing with the rules of trade between nations. Its main function is to ensure that trade flows as smoothly, predictably, and freely as possible. The WTO provides a forum for negotiating agreements aimed at reducing obstacles to international trade and ensuring a level playing field for all, thus contributing to economic growth and development. At the same time, and under the conditions set out in its Agreements, the WTO recognizes the right of members to adopt trade defence measures to achieve legitimate objectives, such as national security, protection of public order, protection of human, animal or plant life, protection of health, and consumer protection.

The WTO commenced on January 1, 1995 in response to a flawed multilateral trading system as regulated since 1947 under the "General Agreement on Tariffs and Trade" (GATT). As of December 31, 2019, it has 164 Members covering more than $98 \%$ of world trade, while 22 other States have observer status and are in the process of accession (WTO, 2020, p.30).

The Arab world is an integral part of the WTO. It corresponds to twenty-two countries that are not only characterized by a circumscribed 
geographical space ranging from the Islamic Republic of Mauritania in the West to the Sultanate of Oman in the East, but also by a common Arabic language and Muslim culture from the time of the Islamic expansion. All these countries belong to the category of developing countries, with a special mention for six of them which are part of the list of Least Developed Countries (LDCs) as defined by the United Nations (UN) (Djibouti, Mauritania, Comoros, Sudan, Somalia and Yemen). Among the Arab countries, thirteen are Members of the WTO and eight others have observer status and are in the process of acceding to this organization.

However, this depiction that has been portrayed conceals another reality. Perceived from the angle of political and economic analysis, the Arab world is far from being unitary and homogeneous. Until now, internal conflicts in the Arab countries have not, in fact, made it possible to capitalize on the advantage offered by "[...] their natural and geographical resources, in close proximity to Europe and in a pivotal position between Europe, Africa and Asia" (Aoudia, 2006, p. 14). This part of the world has not experienced the political and economic dynamics of other emerging zones.

Let us recall that although the Arab countries have 360 million inhabitants, which corresponds to about $6 \%$ of the world's population, their contribution to world trade remains minimal. In fact, while Arab countries represent $5 \%$ of global merchandise exports, this figure is mainly due to exports of hydrocarbons and raw materials by a small number of them (WTO, 2017). The heterogeneity of development levels and economic structure of Arab countries is added to this distressing reality. Three categories of states emerge: high-income countries, whose economies are primarily based on oil and hydrocarbon exports (these are the countries of the Persian Gulf: Bahrain, Kuwait, Oman, Qatar, Saudi Arabia and the United Arab Emirates); middleincome countries whose economy is mainly based on traditional sectors (agriculture and manufacturing) with a growing share of services (including Lebanon, Jordan, Egypt, Morocco, etc.); and low-income countries with an underdeveloped economy mostly based on the agricultural sector (Comoros and Somalia).

Obviously, the presence of the Arab countries within the WTO is an indication of both their fragility within the multilateral trading system and the contradictions that punctuate their relations with the process of liberalization of international trade: contradictions between Arab societies, which are experiencing a strong anti-globalization trend, and the adherence of Arab leaders to the virtues of liberalism; contradiction between the adherence of these Arab leaders to the WTO rounds of negotiations and their weak participation in these rounds; contradiction between the low effectiveness of the WTO's support and technical assistance mechanisms, and the desire to promote better integration of developing countries in general, and Arab 
countries in particular, within the multilateral trading system; contradiction between the desire to give a privileged place to these countries within WTO bodies and the virtual absence of representativity within this institution; contradiction between the large number of Arab countries that are current or potential members of the WTO and their low contribution to world trade. The list of challenges facing Arab countries within the current multilateral trading system goes on. Yet, it is sufficient to demonstrate the close interrelationships between the WTO, the sustainable development of Arab states and the shortcomings of the multilateral trading system in its current functioning with regards to developing countries in general (Kazzi, 2014, p.134).

The purpose of this study is, precisely, to better understand the reasons for these contradictions and the nature of the challenges facing Arab countries within the WTO. In this respect, two ideas will form the basis of the developments that will follow. Firstly, it appears that Arab countries share the conviction that membership in the multilateral trading system is crucial for their sustainable development and their definitive integration into the world economy (2). Secondly, and through an equally antagonistic and contradictory movement, the rounds of WTO negotiations have highlighted the weak impact of Arab countries on the progress of multilateral negotiations, a weakness that characterizes more generally the position of many developing countries in these negotiations and their sense of mistrust towards the functioning of the WTO and the values it conveys (3)

\section{The Arab Countries Willingness to Join The WTO}

The Arab eagerness to join the WTO is based on the Arab countries' conviction that joining the multilateral trading system will ensure the achievement of their strategic objectives; this is why they have not hesitated to adapt to the requirements of free trade.

\section{Adherence to the multilateral trading system in the service of the strategic objectives of Arab countries}

The heterogeneity of levels of development and economic structure, and the diversity of their interests and needs, justifies the classification of Arab countries into the following three categories: high-income countries; middleincome countries; and low-income countries. This heterogeneity vindicates that, beyond the common motives that drive all Arab countries to join the WTO, there are motives that are specific to each of them 


\section{Common reasons for accession to all Arab countries}

The Arab concern to join the multilateral trading system is based on the Arab countries' conviction that free trade is a factor of peace and interdependence between nations.

Taking protectionist measures that restrict trade (such as providing subsidies to sectors threatened by international competition) may be considered advantageous to defend domestic sectors against imports from a short-sighted perspective, but on the long run, a protectionist measure adopted by one country can easily push others to take retaliatory measures. Is it actually conceivable that one country could protect its domestic market without others doing the same? For example, if an Arab country decides to close its borders to foreign agricultural products, how can we prevent these countries from taking retaliatory measures against banks and companies operating in those countries? (Kazzi, 2014, p.138).

Trust helps to avoid such trade wars with no winners. When governments are confident that others will not put up barriers to trade, they are not tempted to do so themselves. They are also much more willing to cooperate. The WTO system plays a crucial role in building and strengthening trust. Negotiations that lead to agreements adopted by consensus, and the priority given to compliance with the rules, are particularly important in this regard.

So the saying: "If goods don't cross borders, soldiers will" (attributed to the economist "Fréderic Bastiat"), is not a theory, but a history lesson, which explains the importance of not only Arab but all other states joining the multilateral trading system.

The Multilateral Trading System (MTS) contributes to the maintenance of peace by providing member states with a constructive and equitable mechanism to settle their trade disputes: the "Dispute settlement understanding" (DSU) (Ghozzi, 2017).

This mechanism is considered the WTO's main institutional advance on the GATT and is administered by the Dispute Settlement Body (DSB). The DSB has authority to establish dispute settlement panels, refer matters to arbitration, adopt panel, Appellate Body and arbitration reports, maintain surveillance over the implementation of recommendations and rulings contained in such reports, and authorize suspension of concessions in the event of non-compliance with those recommendations and rulings (Merrills, 2017, p.205).

The WTO's own Dispute Settlement System also provides member states with the possibility of resorting to alternative dispute settlement mechanisms. Indeed, good offices, conciliation or mediation may be requested at any time by one of the parties to a dispute (Article 5 of the DSU). Article 
25 of the DSU also allows parties to a dispute to resort to arbitration, once they have agreed to the choice of this procedure (Carreau \& Juillard, 2017, p.130).

Thus, the Dispute Settlement System is a guarantee of peace. Once a decision has been taken, countries try to comply with the rules instead of declaring war.

This Arab willingness to join this organization is also motivated by the contribution of the MTS to the economic and social prosperity of nations. In fact, all Arab countries have a common goal: contributing to growth or sustainable economic development in order to increase the standard of living and prosperity of their people. To achieve this goal, these Arab countries aim to join the MTS, believing that compliance with WTO rules will ensure the expansion and liberalization of trade for the well-being of all.

The Arab concern for integration into the MTS is based not only on the conviction of Arab countries that free trade is a factor of peace, stability, and prosperity, but also on the fear of the dangers that would result from bilateral and regional trade agreements.

Certain WTO principles can give vulnerable countries, including Arab countries, the tools to make their voices heard and thus a more favourable position than that granted by regional or bilateral trade agreements. Indeed, regional, and bilateral Preferential Trade Agreements (PTA) can constitute "disguised unilateralism" since they lead to a return to discrimination and the law of the strongest. In these types of agreements, the more powerful countries could impose their will unilaterally on their smaller trading partners. Currently, these countries use these bilateral and regional trade agreements as a tool to achieve their strategic economic and geopolitical objectives, which the MTS has not been able to offer them.

The MTS is rules-based, not power-based. In this system, the rule of law is supposed to replace the law of the strongest. Indeed, WTO agreements are negotiated by all members, and oblige all countries, including the most powerful, to comply with them.

Beyond the risk of spreading unilateralism, there is the danger of the opacity of international trade rules, due to the superimposition of trade agreements, each with its own specificities. Regional and especially bilateral PTA create an increasingly complex set of trade regulations. The principle of non-discrimination, one of the founding principles of the WTO (materialized by the "most-favoured-nation (MFN) clause") avoids this complexity. Indeed, according to this principle, member countries cannot discriminate between their trading partners. For example, if a country grants one of its partners a special favour (a reduction in the customs duties levied on one of its products), it must allow all other WTO members to benefit from it. Similarly, the withdrawal of any concession applied against one Member State automatically extends to all others. Thus, the existence of a single set of rules that applies to 
all members simplifies the trade regime. This is contrary to bilateral treaties that exclude non-signatory trading partners. So, we understand even better the concern of Arab countries to join the WTO.

For Arab countries, the need for a credible alternative to regionalism or bilateralism of trade relations stems not only from the risks mentioned above, but also from the failure of the regional integration paths implemented for decades in Arab countries.

Indeed, there are currently two legal frameworks in which intra-Arab trade takes place: bilateral agreements, and 3 regional agreements: The Gulf Common Market, the Agadir Agreement, and the Greater Arab Free Trade Area (GAFTA). Beyond the specificities of each of them, these 3 agreements have common economic objectives:

- The ultimate goal is to strengthen the economies of the Arab States by creating a more homogeneous market. In other words, these agreements aim to increase trade among member countries (trade among Arab states remains low, less than $10 \%$ of total Arab trade).

- Create favourable conditions for attracting foreign direct investment (FDI).

- Strengthen the negotiating capacities of member countries to deal with powerful trading blocs such as the EU, or in the framework of WTO meetings. (Kazzi, 2014. P.142).

Despite these ambitious objectives, the implementation of these agreements has a rather negative record. There are many reasons for this. First, there are technical obstacles. Indeed, these agreements were concluded hastily, without organization, and inconsistencies have emerged over time. Some signatory states emphasize that a full implementation of their commitments would be a death sentence for several internal sectors, especially in the agricultural and agri-food sector. In addition, some signatory countries have provided a list of sensitive products (wheat, sugar, flour) due to pressure from their farmers and industrialists (Kazzi, 2014, p.143).

Beyond these technical aspects, the impediment to the development of regional economic cooperation is due to the priority given to political rather than economic considerations and the weakness of the institutions responsible for its implementation.

Clearly, bilateral, and regional PTA have been proliferating in recent years. As of January 17, 2020, 303 regional trade agreements were in force. These correspond to 483 notifications submitted by WTO Members (counting goods, services, and accessions separately). Among these agreements, free trade agreements and partial scope agreements (PS) represent 90\%, compared to $10 \%$ for customs unions (WTO, 2019a). In reality, all WTO Members are currently party to one or more PTA, especially as article 24 of the GATT 
considers the conclusion of the agreements to be a special exception to the principle of non-discrimination, as long as certain conditions of substance (not challenging the fundamental principles of the WTO) and form (prior notification to the WTO Secretariat) are respected.

\section{Variable motives according to each Arab country}

Beyond the common motives for all Arab countries to join the WTO, there are specific motives that vary from one country to another, especially since the Arab world is a world fragmented into several categories, each with different interests. The motives for Arab countries to join the WTO differ according to whether they are low, middle, or high-income countries.

Economic diversification: This is a key objective for Arab countries whose economies depend primarily on a single source of income, regardless of whether they are classified as low, middle, or high-income countries. But the difference is in the sectors of activity on which the economy is mainly based. Thus, for high-income countries such as those in the Gulf, dependence is at the oil level (for example, and thanks to measures to diversify the economy, the contribution of the oil sector to Gross Domestic Product (GDP) in Bahrain has not stopped decreasing, in fact, according to World Bank data, it is $18.5 \%$ in 2018). In the other low and middle income countries, it is at the agricultural or service level (for example, Morocco introduced the "Industrial Acceleration Plan 2014-2020 (PAI)" which aims to make industry a major driver of growth and employment by 2020, and to increase the industrial share in GDP by 9 points, from $14 \%$ to $23 \%$ in 2020). The creation of a business-friendly environment capable of attracting the flow of FDI in various sectors is seen as one of the most important tools to achieve this objective.

-Creating employment opportunities: This is a primary goal of many Arab countries, especially the ones most stricken by poverty. Indeed, providing gainful employment for youth, and raising living standards for the population are Egypt's long-term goals since this country suffers from exceptional demography and a high unemployment rate $(12.2 \%$ in 2017 , decreasing to $10.8 \%$ in 2019). Which yields the need to implement an economy that makes the private sector function as the engine of all other sectors, and that intensifies efforts to attract foreign and domestic investment (WTO, 2018, p.19). Unlike Egypt, the Gulf countries do not suffer from a high overall unemployment rate. On the other hand, they suffer from a relatively low representation of nationals in the workforce. According to statistics from the Ministry of Development Planning and Statistics in Qatar: out of a total workforce of 2,175,007 employees in the first quarter of 2020, there are 110,161 nationals and $2,064,846$ expatriates. Hence the objective of these countries to enhance the skills of the national workforce and increase its employment rate (WTO, 2016a, p.5), this is ensured by the improvement of the national workforce 
(through the establishment of training institutes and organizations), as well as by encouraging the flow of foreign and even domestic investment in all economic sectors.

In conclusion, the Arab countries consider the MTS as the tool to achieve all these previously mentioned goals since it is an additional platform to improve and strengthen the flow of FDI.

\section{The adaptation of Arab countries to free trade}

Accession to the WTO is the result of a long negotiation process. Accession therefore involves a balance between rights and obligations, thus bringing benefits while also requiring adjustments. To benefit from the expected advantages of multilateralism, Arab countries did not hesitate to adapt to the WTO's tariff and non-tariff requirements.

\section{Adaptation to tariff requirements}

One of the results of the Uruguay Round was a commitment by members to reduce tariffs and bind their tariff rates to levels that are difficult to raise. For this reason, Arab countries undertook customs adjustments.

In concrete terms, all Gulf GCC countries apply a common external tariff and common customs regulations and procedures. The tariff on most products is either duty free or $5 \%$. A tariff of $100 \%$ or a minimum specific duty is applied to tobacco products. Although nearly all tariffs are below their bound rate, there are 19 tariff lines with a minimum specific duty and, therefore, the ad valorem equivalent could be greater than the $200 \%$ bound duty. Prohibited products include live swine and other products prohibited on security, health, and safety grounds. Restricted products include pig meat products and alcoholic beverages which require import licences and, in most cases, the tariff on these products is $200 \%$ (WTO, 2016a, p.6).

However, accession to the MTS does not only require adaptation to WTO tariff requirements, but also to non-tariff requirements. This presupposes compliance with various WTO agreements. Among these are the following:

-"The Agreement on Import Licensing Procedures":

This agreement strengthens the disciplines on the users of import licensing systems and increases the transparency and predictability.

In fact, Arab countries do not apply any prohibitions or restrictions on trade except when necessary. 
- "The Agreement on the Application of Sanitary and Phytosanitary Measures" (SPS Agreement)):

The SPS Agreement sets out the basic rules for food safety and animal and plant health standards.

It allows countries to set their own standards. But it also says regulations must be based on science. They should be applied only to the extent necessary to protect human, animal, or plant life, or health. And they should not arbitrarily or unjustifiably discriminate between countries where identical or similar conditions prevail. Member countries are encouraged to use international standards, guidelines, and recommendations where they exist (Matsushita, Schonbaum, \& Mavroidis, 2017, p.433).

Kuwait follows the provisions of the SPS Agreements of the WTO. Also, Kuwait's SPS requirements are based on international standards, guidelines, and recommendations. (WTO, 2012, p.17).

\section{-"The General Agreement on Trade in Services (GATS)"}

The GATS is the first multilateral agreement covering trade in services. It applies in principle to all service sectors, with the exception of services that are provided neither on a commercial basis nor in competition with other suppliers and activities that are part of a social security system and other public services, such as health and education services. The objective of this agreement is the liberalization of trade in services (Matsushita, Schonbaum, \& Mavroidis, 2017, p.433).

Jordan also made extensive liberalization undertakings under the GATS; these undertakings would open some sectors that were previously closed or were restricted regarding foreign investment and participation. Jordan has undertaken horizontal commitments with respect to the crossborder movement of individuals and commercial presence covering all types of services. Jordan has made specific commitments in 11 major service sectors and 128 subsectors and activities in all four modes of supply (WTO, 2015, p.8).

\section{Strengthening the competitiveness of national economies}

In respect of the tradition of open trade and in order to meet the needs of an economic environment increasingly characterized by globalization and trade expansion, Arab countries have made the private sector the driving force or the main actor of their economic development. As an example, the Kingdom of Saudi Arabia had made major efforts in privatization. The Council of Ministers had approved the privatization of 20 state-owned utilities, economic activities, and services (WTO, 2016b, p.6).

The success of this process, strengthening the role of the private sector in national development, is mainly ensured by encouraging investment flows, 
which is why Arab countries apply a business-friendly policy through the use of institutional, legislative, fiscal and even financial incentives. Among these are:

- Exemptions or reductions in income tax or corporate tax rates.

- Double Taxation Agreements (which is a treaty between two or more countries to avoid international double taxation of income and property).

- Establishment of free zones (such as Aqaba Special Economic Zone Authority in Jordan (ASEZA) where the investment regime is more liberal than in other parts of the country, attracting domestic and foreign private investments).

- Ensure economic stability, especially monetary and fiscal stability, since they are the main drivers of growth and the main determinants of the level of inward investment (For example, Morocco has implemented a targeted and proactive monetary policy based mainly on improving credit conditions, lowering the policy rate and the reserve ratio, and strengthening the legal framework governing the banking system).

While Arab leaders are convinced that adherence to trade multilateralism is beneficial for their growth, their position within the WTO remains marginal.

\section{The marginalization of Arab countries within the WTO}

The underlying reasons for the weak and marginal position of Arab countries in the WTO are inherent to Arab countries and to the WTO system itself.

\section{Challenges Inherent to Arab Countries}

The marginalization of Arab countries within the WTO can be explained, on one hand, by a lack of Arab expertise in international trade and, on the other hand, by the weak coordination between these countries within the WTO.

\section{Lack of Arab expertise in the field of international trade}

Several indicators point to the weak mastery of WTO rules by Arab countries. The first indicator results from the lack of use of trade defence instruments. In fact, Egypt, Jordan, Morocco, Tunisia and recently GCC member states have already initiated safeguard investigations and applied safeguard measures. In the same direction, Egypt and Morocco are the only Arab countries to have initiated and imposed anti-dumping measures. 
Regarding countervailing measures, Arab countries have neither initiated investigations nor applied such measures to date.

As a reminder, trade defence instruments are used in case of difficulties due to trade liberalization. They ensure "the defence of the legitimate commercial interests of WTO Members when they are victims of unfair practices or are forced to adopt emergency measures in the event of market disruption" (Carreau \& Juillard, 2018, p.335). In this respect, it is difficult to imagine that Arab countries are not affected by unfair practices in third countries. Their inertia may therefore constitute a barrier to the competitiveness of their firms and weaken their position within the WTO.

Beyond the lack of use of trade defence instruments, the weak knowledge of Arab countries in the field of international trade is also justified by the absence of their participation in dispute settlement procedures. In fact, Arab countries' participation in the WTO's Dispute Settlement System is very low. The WTO Annual Report 2020 shows that out of 66 WTO Members that participated in dispute settlement proceedings during the period 1995-2019, no Arab country, except Qatar and Tunisia, initiated a panel proceeding as a complainant (WTO, 2020, p.117).

Egypt has been involved four times as a defendant. For its part, Morocco has also acted as a defendant in only one case. Just noteworthy is the participation of Egypt (10 cases), Qatar (3 cases), Saudi Arabia (33 cases), Oman (11 cases), Kuwait (one case), Bahrain (2 cases) and the United Arab Emirates (3 cases) in WTO dispute settlement proceedings as third parties (WTO, 2019b, p.125).

The infrequent use of the Settlement Dispute System by Arab countries is the result of their lack of expertise and knowledge of the WTO law, a situation aggravated by the increasing complexity of trade disputes. Bringing an action to a WTO panel is a long process that requires the preparation of legal and commercial data and the assistance of experts, lawyers, and economists, able to provide consultations and econometric studies supported by substantial documentation. However, Arab countries have a severe lack of experts in these fields. Despite the terms of art.17 of the DSU according to which the Appellate Body is a permanent body composed of seven members, each of whom is appointed by the DSB for a term of four years renewable once, this composition must be largely representative of WTO Members. Only two Arab experts have sat on the bench of the Appellate Body since 1995, both belonging to the same country, Egypt (Saïd El-Naggar (from 1995 to 2000), and Georges Michel Abi-Saab whose mandate lasted from 2000 to 2004 and then from 2004 to 2008) (Kazzi, 2014, pp. 148-149).

However, an important step has been taken to assist LDCs in WTO dispute settlement through the legal aid mechanism managed by the WTO Secretariat (the Secretariat is required to make available a qualified legal 
expert from the WTO technical cooperation services to any developing country member which so requests) and, most importantly, the creation of the "Advisory Centre on WTO Law" (ACWL). The ACWL gives free legal advice and training on WTO law and provides support in WTO dispute settlement proceedings at discounted rates. These services are available to the developing country members of the ACWL (37 at present) and to LDCs that are members of the WTO or are in the process of acceding to the WTO (44 at present). Out of the 93 countries currently members of the Advisory Centre, there are only nine Arab countries (Egypt, Tunisia, Oman, Jordan, Morocco, Yemen, Mauritania, Djibouti and the United Arab Emirates) which are among the few members that have not yet made use of the support mechanisms available to them.

At the same time, this situation can be explained by the delay taken by Arab administrations and universities to integrate international trade topics in their training. In any case, this weak expertise of Arab countries in the field of international trade has negative repercussions on the representation of these countries within the WTO and the multilateral negotiation process (Kazzi, 2014, p.149).

The presence of Arab delegations in WTO bodies is very limited. The Secretariat is the real coordinator of WTO activities and employs 623 staff members from 82 WTO Members on regular contracts. Among this staff, there are only 13 employees from four Arab countries: 4 employees are from Egypt, 4 employees from Tunisia, one employee from Jordan, and 4 employees from Morocco (WTO, 2020, p.177).

In addition, Arab countries do not have powerful and effective delegations capable of leading negotiations. In other words, they cannot participate fully in the work of the WTO because of the lack of human and financial resources. The diplomatic representations of Arab countries are limited to a handful of people. With its ten-member staff and its participation in all ministerial and other meetings held in Geneva, Egypt is an exception among Arab countries (Kazzi, 2014, p.151).

This low representation of Arab countries in WTO bodies is also reflected in the participation of their Non-Governmental Organizations (NGOs) in ministerial conferences. This participation remains low. For example, at the third ministerial conference held in Seattle in 1999, out of the approximately 739 associations and NGOs that participated, only three were from Arab countries (two were from Egypt: G-15- Chambers of Commerce, Industry and Services Federation, and the Central Union of Agricultural Cooperatives; and one from Sudan: Sudanese Federation of Businessmen and Employers). In addition, only five Arab NGOs were accredited to attend the 10th WTO Ministerial Conference in Nairobi (15-18 December 2015). And 
finally, no Arab NGOs were accredited to attend the 11th WTO Ministerial Conference in Buenos Aires (10-13 December 2017).

In brief, the low representation of Arab countries in WTO bodies is the result of a lack of financial resources and a lack of national experts in the field of international trade.

\section{Lack of coordination among Arab countries within the WTO}

Decision-making methods in multilateral WTO negotiations have changed over time. Decisions are normally taken by consensus, which allows any member country to oppose the final act and prevent its conclusion (right of veto).

In order to circumvent this principle, the industrialized countries have shown that they are ready to negotiate outside the WTO. In fact, previously, under the GATT framework, developing countries were largely excluded from the process of what are called "green rooms". This term refers to negotiations behind closed doors in which only a few countries are invited to participate. The few contracting parties allowed in the "green rooms" negotiate the most important agreements, which provokes resentment from those who remain outside. Even at the very beginning of the WTO, the small group of developing countries admitted to the "green rooms" were invited only as individuals, rather than as representatives of larger groups. Moreover, until the 1990s, the countries of the "Quadrilateral": The United States, the European Union, Japan, and Canada, which were the main trading countries, were the most powerful actors in the search for consensus (Kazzi, 2014, p.144).

Over time, WTO Members relied more on coalitions to mobilize, communicate, and negotiate. As a result, today almost all Developing Countries and LDCs are represented in multiple coalitions formed according to geographical, sectoral, or other criteria.

These coalitions allow these countries not only to be better represented but also to participate in a more informed way in the negotiation process and make their voices heard. These coalitions allow small countries to form a certain balance of power with the more powerful countries in the negotiations.

The Arab countries have divided up into different coalitions in which they appear to be little active (among the main coalitions are: the ACP Group, whose main focus is on issues related to agricultural preferences (60 members including Djibouti, Mauritania, Comoros and Sudan); and the G20, which is a coalition of developing countries seeking ambitious agricultural reforms in developed countries, with some flexibility for developing countries (23 members including Egypt). In fact, their participation in these coalitions does not guarantee them systematic and effective representation, due to a nearabsence of formal recognition, the divergence of interests among their members, a lack of transparency in their functioning, and a radicalization of 
positions between powerful blocs that "[...] have difficulty transforming their defensive power into a positive force that produces tangible results for their members" (Rolland, 2011, p.79).

Aware of this reality and anxious to avoid isolation that would imply a loss of control over the negotiations, the Arab countries decided to form their own coalition within the WTO on 20 June 2006. This group included twelve WTO Member countries (Bahrain, Kuwait, United Arab Emirates, Saudi Arabia, Qatar, Oman, Djibouti, Egypt, Jordan, Tunisia, Morocco, and Mauritania) as well as six other countries with observer status at the WTO, without voting rights (Lebanon, Algeria, Iraq, Sudan, Yemen, Libya).

However, this attempt to create an Arab group failed. This failure is explained on one side by the heterogeneous levels of development and economic structure pertaining to these countries, and on the other side by the conflicts and political rivalries between the Arab countries. In fact, the Arab collective unconscious is unquestionably marked by the need for a powerful political centre. The Arab states seem to be in constant "conflict" to take the place of the only "leader" in the region. Among the main Arab conflicts, we found the Qatari-Saudi rivalry, which appears to only be a game of influence between the two Gulf countries. It began in the 1990s and remains evident until now, especially with the emergence of Qatar as an economic power and one of the richest countries in terms of GDP per capita with the discovery of the North Field, the largest offshore gas field in the world, which worries the Kingdom of Saudi Arabia.

Therefore, we cannot speak of a homogenous Arab world within the WTO, but rather a fragmented whole with divergent interests and needs. Indeed, the Arab countries have difficulties in finding a common position, and in having a minimum level of coordination. The issue of agriculture is symbolic of the difficulties of Arab countries to find a common position. The sole presence of Egypt in the G33, also known as the "Friends of Special Products", might be surprising. In fact, this coalition would like to see some flexibility for the benefit of developing countries to allow them to open their markets to a limited extent in the agricultural sector. However, most Arab countries are net importers of agricultural products, benefiting from the maintenance of agricultural subsidies in developed countries (Kazzi, 2014, p.146). This is the case of the Gulf countries whose agriculture is a negligible sector of the economy.

This situation is mainly explained by the absence of any Arab political will. Arab governments have so far lacked a common strategy to promote some of their economic priorities and vigorously defend their common interests. 


\section{Challenges inherent to the WTO system}

The impact of Arab countries on the progress of multilateral negotiations is small and trivial. The underlying reasons for this situation result from a lack of political will rather than the shortcomings of the WTO and the difficulties of integrating developing countries into the MTS. In fact, the inefficiency of "Special and Differential Treatment" (SDT) and, more generally, the founding theories and guiding principles of the MTS as governed by the WTO, are particularly pointed out.

\section{Questioning the principal of "Special and Differential Treatment"}

SDT is an integral part of the MTS as it has been built since the establishment of the GATT. Indeed, the WTO Agreements include specific provisions that confer special rights to developing countries and LDCs and allow other members to treat them more favourably. The special provisions include:

- longer time periods for implementing agreements and commitments

- measures to increase trading opportunities for these countries

- provisions requiring all WTO members to safeguard the trade interests of developing countries

- support to help developing countries build the infrastructure to undertake WTO work, handle disputes, and implement technical standards

- provisions related to LDCs members

Thus, SDT remains an essential measure for the effectiveness and credibility of the WTO as an institution of development. But despite the evolution of SDT from the GATT years to its most recent form, in practice, it has failed to provide effective and adequate tools to achieve better integration of many developing countries and LDCs into the MTS. This situation of inefficiency is the result of various elements. In fact, the main purpose of the Trade-Related Technical Assistance (TRTA) provided by the WTO Secretariat and, more particularly, by the Institute for Training and Technical Cooperation (ITTC), is to help developing countries build their trade capacity so that they can participate more effectively in global trade.

Technical assistance activities are provided at the global, regional, and national levels (WTO, Annual Report 2020, p.140).

While training instruments have been continuously improved since the creation of the WTO, their added value for Arab States remains limited. The WTO Secretariat undertook just under 300 technical assistance activities in 2019 to help government officials gain a better understanding of WTO rules and the multilateral trading system. More than 18,600 participants benefited. The number of technical assistance activities in which LDCs participated is 50 
per cent. But analysis by region shows that only $4 \%$ of these activities concerned the Arab States and the Middle East, which places this region in the penultimate position, just ahead of the Caribbean zone which received $3 \%$ of technical assistance activities. A detailed analysis of the data provided by the WTO reveals that only $4 \%$ of national technical assistance activities concerned Arab countries, while it is about $11 \%$ for regional activities (WTO, 2020, pp.140-141).

This low number of TRTA activities does not increase the level of expertise in Arab countries in the field of international trade. They need continuous training for Arab officials selected based on competence criteria, as well as an intensification of awareness-raising policies aimed at businesses, parliamentarians, and future decision-makers in these countries (Kazzi, 2014, p.150).

Finally, it should be noted that Arab countries receive different kinds of technical assistance from other international institutions and international donors. Among these institutions:

- The Middle East Regional Technical Assistance Centre (METAC) opened by the International Monetary Fund (IMF). Its mission is to assist members in advancing public policies and institutions that enable inclusive and sustainable growth, so that living standards improve for all citizens.

- The United Nations Development Programme (UNDP), which helps countries develop strong policies, skills, partnerships, and institutions so that they can sustain their progress.

- The United Nations Conference on Trade and Development (UNCTAD), whose main purpose is to maximize the trade, investment, and development opportunities of developing countries and assist them in their efforts to integrate into the world economy on an equitable basis.

But each of these institutions has its own agenda and goals, which can lead to confusion and lack of adequate information.

For this reason, an Arab institution called "The Inter Arab Academy for International Trade Law" can be established to fill this gap in the WTO's technical assistance program. This institution will be financed by contributions and donations from Arab countries in proportion to their level of development. The purpose of this academy is to train an Arab human capital capable of strengthening the capacities of Arab countries to defend their interests. Through this academy, Arab countries will be represented in international organizations (including the WTO) by well-qualified personnel (Malkawi, 2006, p.87). 
So, the multilateral negotiations have highlighted the marginalization of Arab countries within the WTO. The challenge for these countries in current and future negotiations is to train more national experts in the field of international trade and to set up a team of competent and versatile negotiators who can actively participate in working meetings and influence the outcome of negotiations. However, the success of this project depends on a redesign of the WTO's technical cooperation strategy for capacity building, the integration of developing countries, as well as the redefinition of the Secretariat's mandate in this domain (Kazzi, 2014, p.152).

A better differentiation between developing countries would be equally beneficial for Arab countries. The provisions relating to SDT are of a "one-size-fits-all" nature. However, this notion does not consider the fact that the development difficulties encountered by WTO Members are varied and cannot be addressed by uniform rules. This is why Arab countries should advocate a clarification of the generic category of developing countries in order to be able to benefit from technical assistance that is more targeted to their real needs, while avoiding unfair competition from emerging countries, which also benefit from technical assistance and have greater economic advantages (Kazzi, 2014, P.152).

But the question of how to make this differentiation is complex. What are the relevant criteria for differentiation among WTO member countries? As long as this question is not resolved, the issue of differentiation will not move forward, which could lead to a blockage in the multilateral trade negotiations. In fact, differentiation can be made while basing itself on:

I- Criteria related to countries:

- Geographic criteria (regional groupings, factor endowment and geographic location).

- Economic indicators (socio-economic, commercial, institutional).

- Or

- II- Criteria related to the rules:

- SDT objectives (one criterion for each identified objective).

- WTO disciplines (criteria for exemption from disciplines).

One solution could be for the most advanced developing countries to drop out or move away from the groups as their economic and trade situation improves. 


\section{Questioning of WTO principles}

The repeated failures of the WTO ministerial conferences have notably revealed the crisis of confidence in the MTS of southern countries, including the Arab countries. Indeed, these countries are beginning to realize that certain WTO principles run counter to their development needs and interests. This has implied a questioning of the benefits of trade opening.

The process of multilateral negotiations needs to be comprehensively reformed. Despite a formally democratic operating structure, the negotiation process remains in fact controlled by the industrialized countries (Odell, 2005, p.67).

Indeed, multilateral negotiations are based on the consensus rule, which allows any member country (out of 164 today) to oppose the final act and prevent its adoption. This consensus principle tends to strengthen the absolute negotiating power of member states to the benefit of small countries. In order to circumvent this principle, the industrialized countries have in fact shown that they are ready to negotiate outside the WTO (for example, it was at the Organisation for Economic Co-operation and Development (OECD) that the famous Multilateral Agreement on Investment (MAI) was negotiated). These countries, with the support of certain emerging countries, are seeking to "force their destiny" by negotiating in an informal forum parallel to those officially provided by the WTO agreements: the "green rooms". Some developing countries do not wish to change this situation. These are the large developing countries, such as India, Brazil, Argentina, and other emerging countries, which are part of the small circle of elected officials negotiating within the "green rooms" (Kazzi, 2014, p.144). This explains the repeated lack of success of WTO trade negotiations.

The consequence of this situation of exclusion of developing countries from the negotiations is that these countries no longer hesitate to use their right of veto, and above all, no longer hesitate to integrate coalitions within the WTO. But as has already been pointed out, the participation of Arab countries in these coalitions does not guarantee them systematic and effective representation. This is the reason why Arab countries are currently isolated, which means they are losing their grip on the negotiations.

Beyond the need to improve the process of multilateral negotiations, and in order to be able to face the dangers of globalization, it is imperative to have a revision and a renegotiation of certain WTO Agreements and principles that do not really facilitate the integration of developing countries, and specifically Arab countries, into the MTS.

This is the case of the principle of transparency. Transparency is a general obligation imposed on WTO member states that takes two forms: the publication of trade regulations and their notification to the WTO and thus to other countries (Van Den Bosschie, 2016). It is a crucial tool for ensuring 
better predictability of trade, but it does not work as well as it could. Indeed, notifications are disappointing in some areas (subsidies and countervailing measures: 178 notifications in 2019) and excellent in others (sanitary and phytosanitary measures: 1,757 notifications in 2019) (WTO, 2020).

The members and the Secretariat addressed the problem of incomplete or missing notifications from two perspectives. One approach was to consider that the number and complexity of the requirements were at the root of the problem, with some members - especially developing countries - proposing to ease the burden. These concerns, which were reiterated in subsequent years, led to the adoption of several measures to simplify, or clarify the notification process. One such example is the publication of the Step-by-Step Procedures Manual for use by National Authorities Responsible for SPS Notifications, a guide containing detailed instructions on how to meet the notification obligations under the SPS Agreement. The other response to this problem has been for the Secretariat to provide more assistance to developing countries to help them comply with these obligations.

The principle of transparency is not the only fundamental WTO principle that has been criticized. In fact, the questioning of the principle of the Most-favoured-nation (MFN clause) was also put forward. According to this principle, countries cannot normally discriminate between their trading partners. Grant someone a special favour (such as a lower customs duty rate for one of their products) and you must do the same for all other WTO Members.

Despite its importance at the time of the GATT and now in the WTO system, the MFN clause is subject to extensive exceptions that are based on its exact opposite, which is the notion of trade preferences. The 1947 General Agreement legitimized the existence and constitution of PTAs for the sake of regional economic integration or to facilitate border traffic (Article 24). The proliferation of these "clubs" has profoundly contributed to the erosion of the MFN clause and have eroded its former importance while validating notorious trade discrimination. However, its extension to new sectors (starting with services or intellectual property) has given the clause a new lease of life and renewed efficiency. Even if the figures here can only be approximate, it is likely that the MFN clause in its current expanded scope covers about onethird of world trade (Matsushita, Schoenbaum, \& Matsushita, 2017, p.208).

All of these exceptions to the MFN clause through preferential agreements of various nature and scope are now commonly described under the term "spaghetti bowl" formalized by the "Sutherland Report " (2004) on the "Future of the WTO".

Moreover, this principle has not been beneficial to the functioning of the Doha Round negotiations. Many countries are hiding behind this principle to avoid making concessions, while at the same time waiting to benefit from 
the trade advantages granted to certain WTO Members by developed countries. This situation has led to a deadlock in the negotiations.

The challenges of international trade do not stop there. The two founding principles of free trade, as promoted by Adam Smith and David Ricardo, are also called into question. We are talking here about the theory of comparative advantage and the automatic link between trade and development.

According to the theory of comparative advantage, the specialization of a country in the production for which its productivity is the highest in comparison with its partners results in the increase of its national prosperity. But the application of this theory poses more problems than it solves. Indeed, the principle of specialization is regularly advanced to convince economically backward states to open their borders. However, the low economic and industrial development of many Arab countries generates a low added value of the "advantages" available to these countries. Like many developing countries, their trade position is deteriorating because they export products at low prices, while they cannot manage without numerous and expensive imports. The terms of trade are therefore largely in favour of the industrialized countries, even if some countries such as China and India somewhat contradict this reality. In fact, the theory of comparative advantage does not apply to these emerging Asian powers since they have comparative advantages in a growing number of fields (agriculture, industry, services, technology...) and therefore no country has a trade surplus with them.

Globalization has thus widened the gap between those that can integrate into the world market by manifesting comparative advantages, and those that simply do not have the human, energy, and economic resources to face international competition (Kazzi, 2014, p.153).

In addition to the criticisms addressed to the principle of specialization, it is indeed the absence of automaticity in the link between trade and development that is now advanced. In fact, the opening of trade offers effective opportunities for development only under specific conditions that are far from being met in the Arab world: reciprocity of liberalization; creation of the necessary capacities in terms of infrastructure and administration; education and qualification of the population; political and macroeconomic stability, etc....

In fact, for trade to contribute in many ways to the achievement of various sustainable development objectives, it will be necessary to develop policies that promote positive relations between trade policy and other government policies, including social, financial, technological, health, energy, education, environmental, employment, and migration policies.

Regarding education, improving the overall educational level of populations is an important element that contributes to the economic 
dynamism of countries, and to more robust and stable economic growth. In Arab countries, the improvement in education is significant, but it remains limited. In fact, according to the statistics of the "Arab League Educational, Cultural and Scientific Organization", the illiteracy rate in Arab countries is currently $21 \%$ compared to $13.6 \%$ at the global level. Statistics from the United Nations Educational, Scientific and Cultural Organization (UNESCO) indicate that the illiteracy rate for young adults (15-24 years old) in the Arab states is $13 \%$, compared to the global average of $9 \%$. This number is considered huge since young people constitute the basis of the Arab labour force in the near future.

Political stability is also one of the essential conditions for trade liberalization to provide effective opportunities of economic development. Political instability implies a deterioration in the economic situation of the countries. Conflicts weaken the flow of FDI and destroy the resources, capital, and workforce. Although it has only $5 \%$ of the world's population, the Arab region was the scene of $17 \%$ of the world's conflicts between 1948 and 2014, and $45 \%$ of terrorist attacks in 2014. This destroys the economic fabric of the Arab region (UNDP, 2016).

Therefore, to better benefit from trade, Arab leaders must assimilate the fact that trade policy must be at the service of development needs and must implement more cooperation with the private sector and civil society. Beyond the official discourse, this requires a profound change of mentality in order to put an end to the opacity surrounding the conclusion of trade agreements, and to the priority given to political considerations, while the socio-economic impact of the concluded agreements remains vague (Kazzi,2014, p.154).

\section{Conclusion}

In conclusion, the above discussion suggests four observations. Arab countries share the conviction that membership in the MTS is crucial for their sustainable development and their mooring in the global economy. In response to the dangers that would result from bilateral trade agreements, and in response to the failure of further regional integration, multilateralism is currently the most appropriate path for Arab countries in terms of development policies.

The WTO rounds of negotiations have highlighted the weak impact of Arab countries on the progress of multilateral negotiations. This situation is due to a lack of expertise of these countries in international trade. This is why it is urgent to improve their expertise on the WTO system through an awareness raising policy, and a training policy on international trade in universities and competent administrations.

The low impact of Arab countries on multilateral negotiations also results from the lack of any coordination among them, and from their 
dispersion in coalitions within the WTO. Actually, the attempt to establish an Arab alliance in 2006 among Arab countries has failed. This failure was due to political rivalries among Arab countries, as well as the heterogeneity of their levels of development and economic structures. This alliance must therefore be revitalized in order to provide a platform for expressing their interests: its objective is to set itself up as a key interlocutor in front of the large delegations and other groups involved in the WTO trade negotiations.

The underlying reasons for the marginalization of Arab countries within the WTO also stem from the shortcomings of the WTO, which does not fully meet the integration needs of developing countries in general, and Arab countries in particular. A renegotiation of certain WTO agreements and principles is thus necessary to improve the situation of Arab countries within this organization.

\section{References:}

1. Aoudia, J.O. (2006). Growth and reforms in the Arab Mediterranean countries. Retrieved from https://www.afd.fr/en

2. Carreau, D., \& Juillard, P. (2017). International Economic Law. Paris, France: Dalloz.

3. Ghozzi, M.A. (2017). General principles in the jurisprudence of the WTO Dispute Settlement Body. Paris, France: L'Harmattan.

4. Kazzi, H. (2014). Arab countries and the Doha round: Between ambition and reality. Journal of International Economic Law, 1 (2), 131-155. doi: 10.3917/ride.282.0131

5. Malkawi, B.H. (2006). Jordan and the World Trading System: A case study for Arab countries (S.J.D. Dissertation, American University, Washington, United States). Retrieved from https://www.wcl.american.edu/

6. Matsushita, M., Schoenbaum, T.J., \& Mavroidis, P.C. (2017). The World Trade Organization: Law, Practice, and Policy.doi: 10.1093/law/9780199571857.001.0001

7. Merrills, J.G. (2017). International Dispute Settlement. New York, United States of America: Cambridge University Press.

8. Odell, J.S. (2005). Chairing a WTO negotiation. Journal of International Economic Law, 8 (2), 425-448. Retrieved from https://academic.oup.com/jiel

9. Rolland, S.E. (2011). State groupings and coalitions at the WTO: In search of a legal framework. In Garcia, T.H., \& Tomkiewicz, V. (Eds.), The World Trade Organization and the subjects of law (79-94). Brussels, Belgium: Bruylant. 
10. UNDP. (2016). Arab Human Development Report: Youth and the prospects for human development in changing reality. Retrieved from https://www.arabstates.undp.org/content/rbas

11. /en/home.html

12. Van Den Bossche, P. (2016). Essentials of WTO Law. New York, United States: Cambridge University Press.

13. WTO. (2012). Trade Policy Review: Report by the government-Kuwait (WT/TPR/G/258).

Retrieved

from https://www.wto.org/english/tratop_e/tpr_e/tp358_e.htm

14. WTO. (2015). Trade Policy Review: Report by the government-Jordan (WT/TPR/G/325).

Retrieved

from https://www.wto.org/english/tratop_e/tpr_e/g325_e.pdf

15. WTO. (2016a). Trade Policy Review: Report by the governmentUnited Arab Emirates (WT/TPR/G/338). Retrieved from https://www.wto.org/english/tratop_e/tpr_e/g338_e.pdf

16. WTO. (2016b). Trade Policy Review: Report by the government-The Kingdome of Saudi Arabia (WT/TPR/G/333). Retrieved from https://www.wto.org/english/tratop_e/tpr_e/g333_e.

17. pdf

18. WTO. (2017). World Trade Statistical Review. Retrieved from https://www.wto.org/english/r

19. es_e/statis_e/wts2017_e/wts2017_e.pdf

20. WTO. (2018). Trade policy Review: Report by the secretariat-Egypt (WT/TPR/S/367).

Retrieved

from

https://www.wto.org/english/tratop_e/tpr_e/s367_e.pdf

21. WTO. (2019a). Regional trade agreements. Retrieved from https://www.wto.org/english/tratop

22. _e/region_e/region_e.htm

23. WTO. (2019b). Annual Report. Retrieved from https://www.wto.org/english/res_e/booksp_e/a

24. nrep19_e.pdf

25. WTO. (2020). Annual Report. Retrieved from https://www.wto.org/english/res_e/booksp_e/anrep_e/anrep20_e.pdf 